\title{
Szemere György professzor (1931-2016), az első vidéki genetikai tanácsadó megteremtője
}

Dr. Szemere György 1931. február 3-án született Üllőn, és 2016. szeptember 7 -én halt meg Szegeden. Halálának egyéves évfordulóján tisztelettel emlékezünk munkásságára.

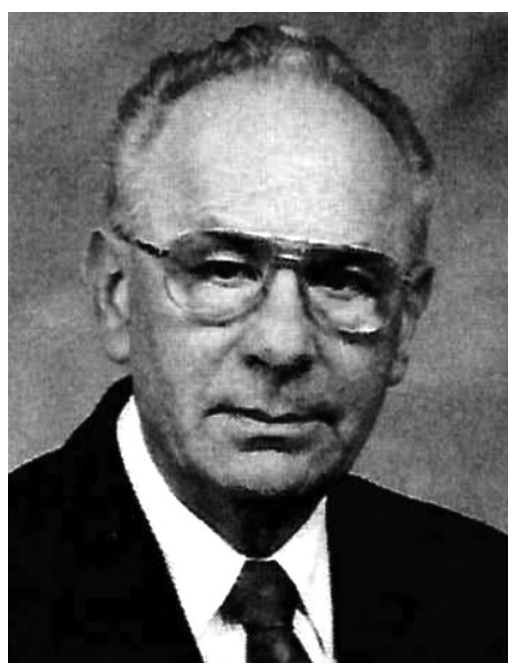

Iskoláit Budapesten kezdte, ahol a háborúig a Kölcsey Gimnáziumban tanult. A világháborúban elvesztette édesapját, ezért 1945-ben Szegedre költözött a család orvos nagybátyjához, akitől élethivatását örökölte.

Egész szakmai pályafutását a Szegedi Tudományegyetem egyik jogelődjén, a Szent-Györgyi Albert Orvostudományi Egyetemen töltötte, előbb az Orvosi Biológiai Intézetben, majd az általa alapított Orvosi Genetikai Intézetben. 1949-től 1955-ig a Szegedi Orvostudományi Egyetemnek volt hallgatója, és 1955-ben szerzett orvosi diplomát „summa cum laude” minősítéssel. Az újonnan alakult Orvosi Biológiai Intézetbe Gelei József profeszszor meghívására került, ahol 1955-ben, szigorló orvos korában gyakornoki kinevezést kapott. Pályája gyorsan ívelt, tanársegéd, adjunktus, docens, majd 1977-ben egyetemi tanár lett. Laboratóriumi szakorvosi képesítést 1960-ban szerzett, humángenetikus képesítéssel 1979től rendelkezett. Az orvostudomány kandidátusa címet 1972-ben, az orvostudomány doktora címet „Elsődleges és másodlagos genetikai prevenció” címü munkájával 1989-ben nyerte el.

Dr. Szél Évával 1959-ben kötött házasságot, és 45 évig éltek kiegyensúlyozott, boldog házasságban.
Szegeden 1964-ben létrehozta az első vidéki genetikai tanácsadót, ahol az országban az elsők között alkalmazta a citogenetikát a genetikai tanácsadói gyakorlatban. 1990-ben megszervezte és első igazgatója volt a Szegedi Orvosi Genetikai Központnak, majd azt 1994-ben tanszékké, a mai Orvosi Genetikai Intézetté fejlesztette.

Tudományos tématerületei a genetika, humángenetika, praenatalis genetika, a properdin- és komplementrendszerek, citogenetika, meioticus vizsgálatok. Egy tankönyvet, négy könyvfejezetet, kilenc egyetemi jegyzetet írt, több mint száz tudományos dolgozata jelent meg és több száz tudományos, ismeretterjesztő, valamint továbbképző előadást tartott itthon és külföldön. Közel félszáz külföldi kongresszuson vett részt.

Nápolyban 1964-ben, Koppenhágában 1967-ben, Edinburghban 1968-ban három hónapig, majd 197475-ben ugyanitt egy évig volt tanulmányúton.

A szegedi egyetem legjobb oktatói között tartották számon, mint kivételesen elhivatott oktatót, aki 50 tanéven keresztül oktatta és nevelte az orvos-, a gyógyszerész- és egészségügyi főiskolai kar hallgatóit, de gyakori felkért oktató volt a Juhász Gyula Tanárképző Fooiskolán is. Elméleti és gyakorlati órákat tartott magyar és angol nyelven, valamint több évtizeden keresztül vezetett humángenetikából speciális kollégiumot. Előadásai élményszámba mentek, okosan keverte a humort a tudománnyal, így az előadásain soha nem volt unatkozó hallgató.

Szemere professzor a humángenetika hazai megalapítói közé tartozik, azok közé, akiknek lelkesedése, tudományos és gyakorlati tevékenysége lehetővé tette a humángenetika hazai fejlődését a nem túl kedvező, csaknem mostoha körülmények között is. Életmúvével bizonyította, hogy egy alapvetően elméleti egyetemi intézetben is lehetséges a közvetlen betegellátással kapcsolatos fontos tevékenységet kifejteni. Alapító tagja volt a Magyar Humángenetikai Társaságnak, 10 éven át töltötte be annak elnöki funkcióját. 1991-től 1997-ig két cikluson át töltötte be a Szent-Györgyi Albert Orvostudományi Egyetem Általános Orvostudományi Karának dékáni tisztségét. Több mint egy évtizedig volt a Közmúvelődési Bizottság elnöke, ezt a munkáját a Szocialista Kultúráért Érdeméremmel honorálták. Egy cikluson át a magyar Orvostudományi Társaságok és Egyesületek Szövetségének (MOTESZ) alelnöke volt, az itt végzett munkáját 
MOTESZ-díjjal, az intézet és az orvoskar vezetésében betöltött szerepét pedig a Magyar Köztársasági Érdemrend tisztikeresztjével ismerték el. Szemere professzor 2001. február 3-tól haláláig a Szegedi Tudományegyetem Általános Orvostudományi Karának emeritus professzora volt.

Számos szenvedélyes hobbija volt, amelyek közül hármat emelnénk ki. Nagy kutyabarát volt, ezt a hobbiját professzionális szinten űzte. A Magyar Ebtenyésztők Egyesületének elnökségében többször megválasztott elnökségi tag, nemzetközi küllembíró, a magyar pásztorkutyák kiváló bírója, a puli szerelmese volt. Kutyamagazinokban számos, genetikai témájú írása jelent meg. Élmény volt vele kutyás témákról beszélgetni.

Másik szerelme (felesége mellett) a komolyzene volt. Nem volt Szegeden olyan zenei bemutató, ahol ő meg nem jelent volna.

Végül az utazásai! Feleségével turistaként a világ számos országában jártak, visszatérésük után kiapadhatatlan volt az aktuális élményeiból.

Szemere professzor azon kevesek egyike volt, aki végig megőrizte emberségét a barátaival, kollégáival, a hallgatókkal, ezért is nagyon sokan érezzük hiányát. Emlékét tisztelettel megőrizzük!

Egy ember hagyatéka az életmúve, egy tudós orvosé a betegek hálája. Foglaljuk össze, mit végzett a vezetése alatt múködött genetikai tanácsadó a betegek szolgálatában.

Az SZTE Orvosi Genetikai Intézetben folyó munka fó célja a genetikai prevenció. Szemere professzor úr „Genetikai prevenció, genetikai tanácsadás és/vagy praenatalis diagnosztika" címmel a Magyar Alapellátási Archívumban 1999-ben a szerkesztőség felkérésére írt tanulmányában foglalta össze a két módszer lényegét, s egyben hangsúlyozta, hogy a két módszer egymástól nem választható el, s csak együtt, egymást kiegészítve van létjogosultságuk. Megfogalmazta a genetikai tanácsadás lényegét, a genetikai tanácsadásra utalás indokait, valamint elöre jelezte a genetikának az orvosi gyakorlatba való bevezetését, a genetikai tanácsadó és a társszakmák várható egyre szorosabb együttmúködését [1]. Az Egészségügyi Minisztérium genetikai tanácsadásra vonatkozó szakmai protokolljának kidolgozásánál a Klinikai Genetikai Szakmai Kollégium nagymértékben támaszkodott az ország vezető klinikai genetikusainak, köztük Szemere professzor úr több évtizedes munkájának tapasztalataira.

Szemere professzor úr már 1999-ben hangsúlyozta, hogy „az alapellátásban dolgozó szakemberek elemi kötelessége, hogy ismerjék a genetikai tanácsadásra utalás indokait" [1]. Az általa felsorolt javaslatok ma is érvényesek. Az optimális családtervezés és a sikeres genetikai ellátás érdekében a tervezett terhesség előtt javasolt a rendelésen jelentkezni, ha a családban több családtagnál hasonló klinikai tünetekkel járó betegség, Down-szindróma vagy egyéb kromoszóma-rendellenesség, anyagcsere-betegség, fejlődési rendellenesség, esetleg ritka be- tegség fordul elő. Hasonlóképpen érdemes felkeresni a genetikai szakellátást, ha a szülők között rokoni kapcsolat van. Sikertelen gyermekvállalás (női és férfi meddőség, ismétlődő vetélések) genetikai okainak feltárásával segíteni lehet a családoknak az áhított terhesség megfoganását, sikeres kiviselését. Megfogant terhesség esetén javasolt klinikai genetikushoz fordulni a kora terhességi gyógyszer-, vegyi, illetve sugárexpozíció esetleges magzati ártalmat okozó hatásának megállapítására, a magzati fejlődési rendellenességek felismerését célzó vizsgálatok megszervezésére.

Az egyik leggyakoribb genetikai betegség a Downszindróma, amelynek megelőzéséhez hasznos segítséget ad a 35 évnél idősebb várandós anyák tájékoztatása a széles körű szűrő- és diagnosztikai vizsgálatok elérhetőségéről, javaslatáról. Genetikai tanácsadáson indokolt jelentkezni valamennyi olyan várandósnak, akinél a különböző szűrővizsgálatok eredménye alapján a magzati fejlődési/ kromoszóma-rendellenességek kockázata emelkedett. Egyre több népbetegség (szív- és érrendszeri, gyomorbél rendszeri, daganatos betegség) családi halmozódása esetén az ellátás szerves része a hajlamosító genetikai faktorok vizsgálata szakorvosok javaslatára.

A genetikai tanácsadó ambulancia múködésének szükségességét a genetikai tanácsadás számának növekedése támasztja alá a különböző klinikai szakterületek igényének teljesítésére. Francis S. Collins és Victor A. McKusick 2001-ben „A Humángenom Projekt hatása az orvostudományra" cikkükben már leírták, hogy néhány traumás eset kivételével valamennyi emberi kórképnek van genetikai komponense [2]. Napjainkra a legtöbb emberi betegség esetén fény derült genetikai okra, hajlamosító tényezőre. A genetika tudománya 2017-re a hétköznapi betegellátás szerves részévé vált. A modern genetikai laboratóriumi vizsgálómódszereknek (teljesgenom-, illetve exomszekvenálás) klinikai gyakorlati elérhetőségének köszönhetően módunkban áll monogénes betegségek kóroki mutációinak diagnosztikus, preszimptomás, praenatalis meghatározása, valamint poligénes betegségeknél a kórállapot kialakulására hajlamosító géneltérések (mutációk, polimorfizmusok) prediktív tesztelése. A genetikai tanácsadó orvos ma az esetek jelentős hányadában személyre szabott információt tud adni, szemben a humángenetika forradalmát megelőző kor genetikai kockázatelemzésével. A genetikai tanácsadás új területtel, a genomikai tanácsadással [3] bővült a korábban kialakult specializációk (praenatalis, gyermekgyógyászati vagy tumorgenetikai tanácsadás) mellett.

Az 1. ábra szemlélteti az SZTE Orvosi Genetikai Intézet Genetikai Tanácsadó Ambulanciáján végzett genetikai tanácsadások számát 1995. január 1. és 2017. augusztus 31. között. (1995. 01. 01.-1999. 12. 31.: 7851 [1570/év], 2000. 01. 01.-2004. 12. 31.: 5768 [1153/ év]; 2005. 01. 01.-2009. 12. 31.: 13127 [2625/év]; 2010. 01. 01.-2014. 12. 31.: 13969 [2793/év]; 2015. 01. 01.-2017. 08. 31.: 6067 [3033/év]). 


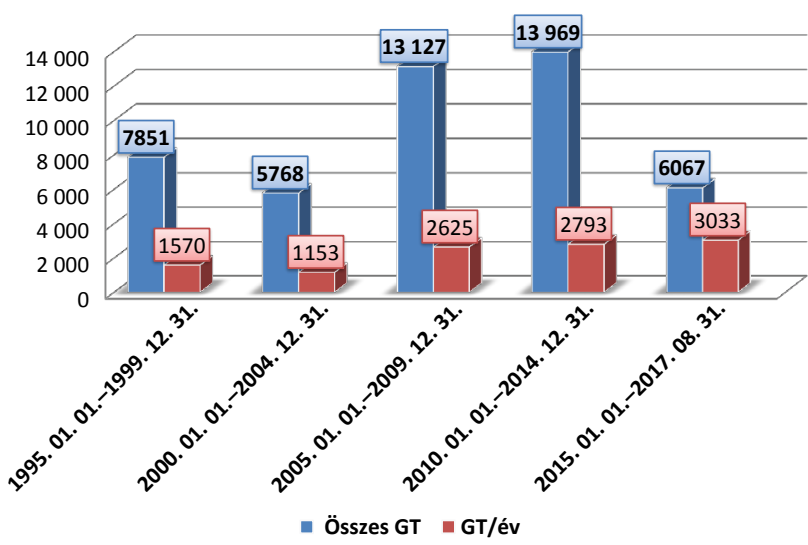

1. ábra $\quad$ A genetikai tanácsadások számának növekedése az SZTE Orvosi Genetikai Intézetben, 1995-2017

$\mathrm{GT}=$ genetikai tanácsadás

Míg korábban a genetikai tanácsadás elsősorban a szülészet-nőgyógyászati, valamint a csecsemő- és gyermekgyógyászati munka szerves része volt, ma egyéb klinikai szakterületekkel szorosan együttmúködve jelentősen hozzájárul a legkülönbözőbb betegségek megelőzéséhez, sikeres kezeléséhez, prognózisának ismeretéhez.

A 2. ábrán szemléltetjük az SZTE Orvosi Genetikai Intézet Genetikai Tanácsadó Ambulanciája szoros együttmúködését a Szegedi Tudományegyetem Klinikai Központjának egyéb egységeivel, valamint hazai és külföldi laboratóriumokkal a multidiszciplináris betegellátás igényeinek kielégítésére.

Szemere professzor úr az országban az elsők között alkalmazta a citogenetikát a genetikai tanácsadói gyakorlatban, így a vezetése alatt múködött genetikai tanácsadó elsősorban a kromoszóma-rendellenességek vizsgálatá- val, magzati és szülést követő felismerésével állt a betegek szolgálatában. Az általa vezetett citogenetikai laboratóriumban elhivatott, magas szakmai felkészültségű humángenetikai szakasszisztensek által végzett prae- és postnatalis citogenetikai vizsgálatok (praenatalis: $\mathrm{n}=10$ 715; postnatalis $\mathrm{n}=16200$ ) eredményeként az 1 . és 2. táblázatban összefoglalt számbeli és szerkezeti kromoszóma-rendellenességgel született betegeket $(\mathrm{n}=1040)$, magzatokat $(\mathrm{n}=37 \mathrm{l})$ sikerült diagnosztizálni. Munkatársaival (Szabó János és Gellén János professzorral) dolgozták ki a magzati citogenetikai rendellenességek felismerését szolgáló hatékony szürō- és diagnosztikai módszereket, amelyről számtalan tudományos folyóiratban számoltak be [4-8].

A 3. ábrán szemléltetjük az SZTE Szülészeti és Nőgyógyászati Klinikán 1984 és 2016 között történt magzati citogenetikai vizsgálatokhoz szükséges invazív mintavételek különböző típusainak megoszlását: Chorionboholy-mintavétel (CVS) n = 2680 (25\%); köldökzsinórvér-mintavétel (cordocentesis) $\mathrm{n}=632(6 \%)$, valamint magzatvíz-mintavétel (amniocentesis), $\mathrm{n}=7403$ (69\%).

A MOTESZ Magazinban 2000-ben „Prenatális cytogenetikai diagnosztika" címmel megjelent összefoglalójában Szemere professzor úr hangsúlyozta, hogy a kromoszóma-rendellenességek elkerülése a preventív medicina fontos szakterülete [9]. Jelen gyakorlatunkat „Az Emberi Erőforrások Minisztériuma szakmai irányelve a Down-kór prenatális szüréséről és diagnosztikájáról" határozza meg (hatályos 2016. 12. 22-től). Noha ma már a magzati citogenetikai rendellenességek felismerésében egyre jelentősebb szerepet játszanak az anyai vérben meghatározható szabad magzati DNS kimutatásán alapuló másodlagos szû́rések (NIPT), az ultrahang-
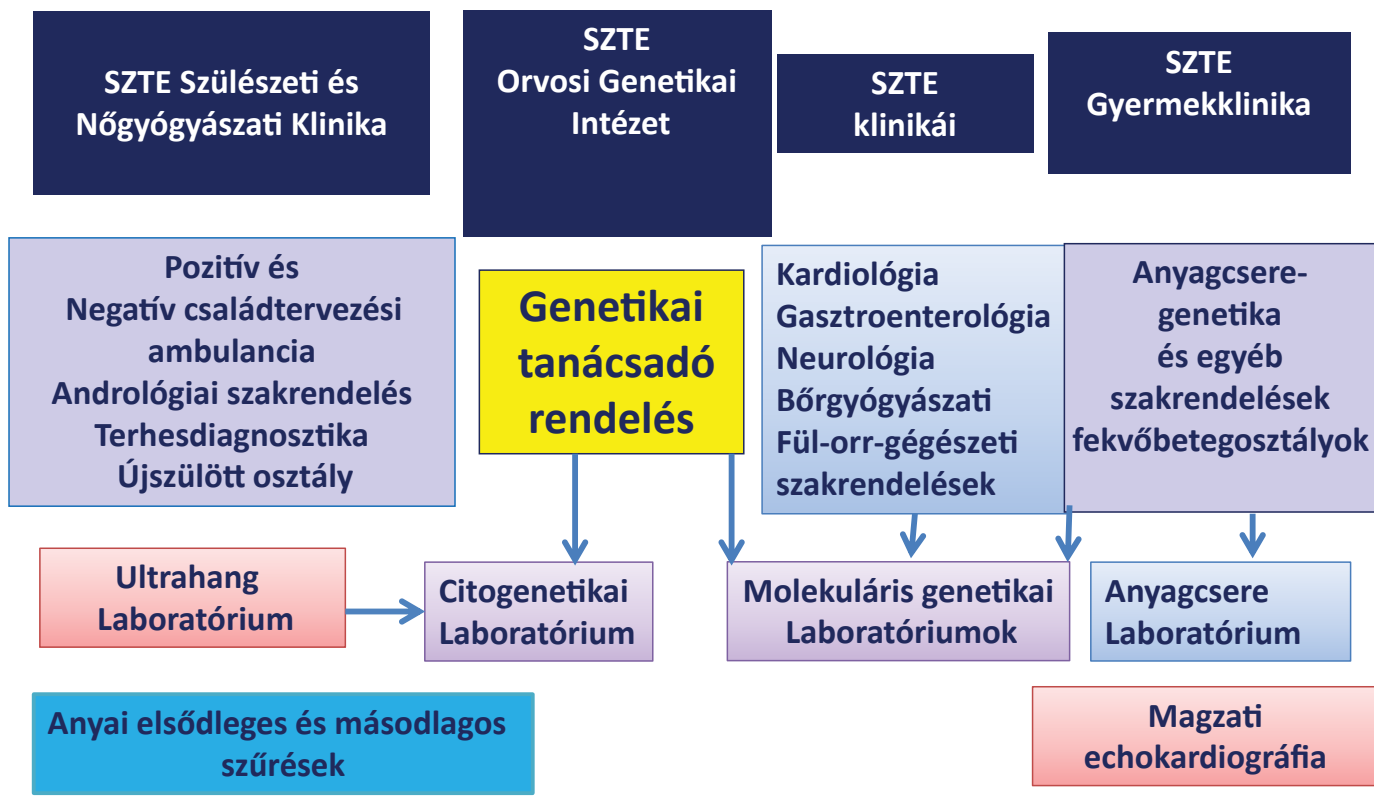

$$
\text { szúrések }
$$

Magzati echokardiográfia 


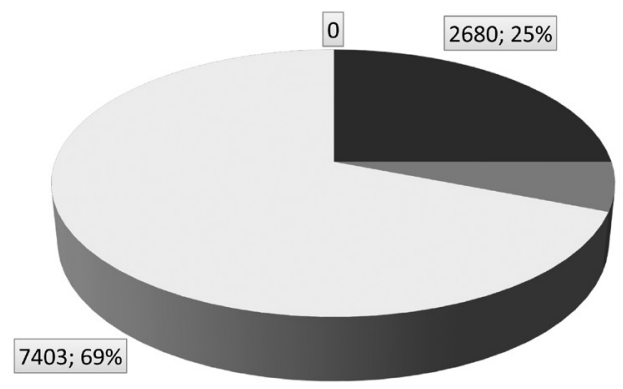

$632 ; 6 \%$

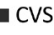

- Cordocentesis AC

Invazív mintavételek száma az SZTE Szülészeti és Nőgyógyászati Klinikán, 1984-2016

CVS $=$ (chorionic villus sampling) chorionboholy-mintavétel $\mathrm{AC}=$ amniocentesis

vizsgálatok, az elsődleges szürőmódszerek, valamint az invazív mintavétellel elvégezhető citogenetikai vizsgálatok továbbra is fontosak.

Szemere professzor úr gyakorlati és tudományos munkássága a genetikai tanácsadás és praenatalis diagnosztika területén nagyon sok családot segített az örömteli, pozitív családtervezéshez, követendő példát mutatva valamennyi gyakorló klinikai genetikus számára.

1. táblázat | Családtervezés, illetve csecsemő-gyermek korban az SZTE Orvosi Genetikai Intézetben elvégzett kromoszómavizsgálatok eredményei, 1970-2016

\begin{tabular}{lc}
\hline Kromoszóma-rendellenesség & $\mathrm{n}$ \\
\hline Down-szindróma & 549 \\
Edwards-szindróma & 16 \\
Patau-szindróma & 7 \\
Turner-szindróma & 121 \\
Klinefelter-szindróma & 87 \\
Kiegyensúlyozott transzlokáció & 115 \\
Deléció & 35 \\
Inverzió & 10 \\
Mozaik karyotypus & 28 \\
Egyéb (intersex, YY, XXX) & 72 \\
\hline Összesen & 1040 \\
\hline
\end{tabular}

2. táblázat $\mid$ Magzati citogenetikai vizsgálatok eredményei az SZTE Orvosi Genetikai Intézetben, 1984-2016

\begin{tabular}{lc}
\hline Kromoszóma-rendellenesség & $\mathrm{n}$ \\
\hline Down-szindróma & 175 \\
Patau-szindróma & 28 \\
Edwards-szindróma & 52 \\
Triploid magzat & 18 \\
Turner-szindróma & 25 \\
Klinefelter-szindróma & 11 \\
Kiegyensúlyozott transzlokáció & 31 \\
Egyéb (intersex, YY, XXX) & 31 \\
\hline Összesen & 371
\end{tabular}

\section{Irodalom}

[1] Szemere Gy, Faragó M, Horváth E. Genetic prevention. Genetic counselling and/or prenatal diagnostics. [Genetikai prevenció. Genetikai tanácsadás és/vagy prenatalis diagnosztika.] Magyar Alapellátási Archivum 1999; 90-93. [Hungarian]

[2] Collins FS, McKusick VA. Implication of the Human Genome Project for medical science. JAMA 2001; 285: 540-544.

[3] Mills R, Haga SB. Genomic counseling: next generation counseling. J Genet Couns. 2014; 23: 689-692.

[4] Szabó J, Gellén J, Szemere G, et al. Significance of hyper-echogenic yolk sac in first trimester screening of chromosome abnormalities. [Hyperechogen szikzacskó jelentősége a kromoszómarendellenességek első trimeszteri szürésében.] Orv Hetil. 1996; 137: 2313-2315. [Hungarian]

[5] Szabó J, Gellén J, Szemere G. First-trimester ultrasound screening for fetal aneuploidies in women over 35 and under 35 years of age. Ultrasound Obstet Gynecol. 1995; 5: 161-163.

[6] Szabó J, Gellén J, Szemere G. Nuchal edema as an ultrasonic sign of trisomy 21 during the first trimester of pregnancy. [Nuchalis oedema a 21 -es triszómia első trimeszteri ultrahang jele.] Orv Hetil. 1992; 133: 3167-3168. [Hungarian]

[7] Szabó J, Gellén J, Szemere G. Non-immune hydrops in trisomy-18. Diagnosis by vaginosonography and chorionic villus sampling in the first trimester. Case report. Br J Obstet Gynaecol. 1990; 97: 955-956.

[8] Szabó J, Gellén J, Szemere G. Why confine chorionic villus (placental) biopsy to the first trimester? Lancet 1986; 327: 1030.

[9] Szemere Gy, Szabó J, Faragó M, et al. Prenatal cytogenetic diagnostics. [Prenatális cytogenetikai diagnosztika.] MOTESZ Magazin 2000; 4: 17-22. [Hungarian]

(Raskó István dr. és Horváth Emese dr., Szeged, Somogyi B. u. 4., 6720 e-mail: horvath.emese@med.u-szeged.hu)

\section{„Felix qui potuit rerum cognoscere causas." (Vergilius) (Boldog, ki képes a dolgok okait megismerni.)}

